\title{
PENINGKATAN OMZET MELALUI PELATIHAN PENCATATAN KEUANGAN DAN PERENCANAAN PEMASARAN STRATEGIS PADA SYMPHONY COFFEE BANDUNG
}

\author{
Fia Dialysa \\ fdialysa@gmail.com \\ Anton Mulyono Azis \\ anton.mulyono@ekuitas.ac.id \\ Mohamad Hadi Prasetyo \\ hadi.p@ekuitas.ac.id
}

\section{SEKOLAH TINGGI ILMU EKONOMI EKUITAS}

\begin{abstract}
ABSTRAK
Tujuan dari program ini ialah untuk memberikan pelatihan pencatatan keuangan dan perencanaan pemasaran strategis pada Symphony Coffee Bandung. Pengabdian pada masyarakat ini dilakukan sebagai salah satu upaya dalam meningkatkan keterampilan dan kemampuan usaha agar dapat bersaing di pasar dan dapat meningkatkan kelas usaha dari para pelaku usaha serta berujung pada meningkatnya total pendapatan. Masalah yang terjadi disini ialah para pelaku usaha tidak melakukan sistem pencatatan keuangan yang sistematis sehingga berdampak pada tidak terlihatnya marjin keuntungan antara modal dengan biaya yang dikeluarkan. Hal itu juga berpengaruh pada perencanaan pemasaran pada periode berikutnya. Metode dalam program ini dibagi menjadi tiga tahapan, yaitu pengenalan masalah, prosedur kerja, dan kegiatan yang dilakukan. Objek pengabdian kepada masyarakat ini adalah Symphony Coffee di Jl. Margacinta no. 192 Bandung.
\end{abstract}

Kata kunci: Pelatihan Pencatatan Keuangan, Strategic Marketing Plan, Symphony Coffee Bandung.

\section{PENDAHULUAN}

Kota Bandung merupakan salah satu kota kuliner diantara kota-kota lain di Indonesia. Kota Bandung memiliki penduduk sebanyak 2.490.622 jiwa dengan laju pertumbuhan penduduk $0.37 \%$ dan tingkat kepadatan penduduk mencapai 15.713 orang per $\mathrm{km}^{2}$ (BPS Kota Bandung, 2017). Banyak sekali makanan dan minuman khas yang berasal dari kota berjulukan Kota Kembang ini. Seperti yang diketahui, Bandung adalah tempat bagi mereka yang mencari sensasi berkuliner dan berbelanja. Berkat dataran tinggi dan gunung-gunung di sekelilingnya, Kota Bandung memiliki hawa sejuk dan panorama alam yang indah. Kota Bandung juga merupakan pusat perkembangan dan industri, hal ini juga didukung dengan banyaknya berbagai kegiatan yang di selenggarakan di Bandung. Karena itu Bandung mempunyai daya tarik para kaum urban untuk mencari pekerjaan. Banyaknya pendatang dari berbagai daerah ke kota Bandung untuk menuntut ilmu atau 
mencari pekerjaan menjadikan penduduk kota Bandung sangat heterogen.

Selain terkenal dengan daerah wisata belanja Bandung juga terkenal sebagai pusat kuliner, baik kuliner lokal maupun internasional. Maka dari itu Kota Bandung merupakan salah satu yang berpotensi untuk berbisnis maupun berwirausaha.

Selain itu, banyak peluang yang dapat di manfaatkan bagi para pelaku bisnis. Dengan adanya pergeseran nilai budaya dari masyarakat sosial yang terjadi saat ini, masyarakat menjadi cenderung lebih individual.

Berbagai aktivitas dilakukan oleh masyarakat untuk melepaskan kepenatan. Salah satu carayang dilakukan oleh masyarakat ialah dengan melakukan aktivitas sosial bersama rekan kerabat sambil bersantai untuk sekedar menikamti makanan ringan dan meminum kopi. Karena hal tersebut, didapat peluang dari pergeseran gaya hidup masyarakat yang menjadikan kegiatan tersebut sebagai bagian dari kebutuhan hidup. Peluang itu akan merangsang bisnis food services seperti café atau secara sederhana disebut warung.

Belakangan ini banyak anak muda yang biasa disebut kaum milenial membutuhkan sebuah ruang untuk berkreasi atau kebutuhan untuk mencari hiburan. Jawaban yang tepat untuk saat ini ialah café. Café merupakan salah satu tempat yang dimana sering didatangi oleh banyak orang baik itu untuk memuaskan kebutuhan makan dan minum ataupun sekadar bersosialisasi dengan kerabat. Café saat ini sebagai sebuah gaya hidup bagi kaum milenial dimana semua hal bisa dilakukan di tempat tersebut. Café merupakan salah satu tempat yang menyediakan berbagai jenis makanan dan minuman yang didukung dengan atmosfer warung yang diyakini dapat mewakili perasaan dan gaya dar berbagai kelas sosial.

Café dapat menjadi solusi yang dapat dimanfaatkan sebagai tempat untuk melakukan pertemuan sosial. Dalam hal ini café disebut sebagai warung. Ini hanyalah perbedaan istilah yang tertanam dibenak masyaraat.

Atmosfer yang terbilang comfy dan berbagai menu yang ditawarkan merupakan salah satu dari berbagai alasan para kaum urban memilih café atau warung sebagai tempat berkumpul. Hal ini yang mendasari adanya Symphony Coffee sebagai salah satu kafe yang memanfaatkan peluang tersebut. Symphony Coffee memiliki banyak variasi menu minuman khususnya kopi. Menu rumahan didukung oleh kopi berkualitas untuk menemani konsumen dalam menghabiskan waktu di symphony coffee. Desain interior yang simple membuat para konsumen menjadi betah berlama-lama dan bersantai. Symphony Coffee baru memulai bisnisnya sekitar beberapa bulan yang lalu, disini sebenarnya terlihat potensi yang tinggi terhadap sebuah bisnis yang dapat dikatakan bisnis rumahan. Dari hal tersebutlah tercipta ide bahwa bermula dari bisnis rumahan dapat meraih keunggulan kompetitif. Banyak sekali pelaku usaha melakukan pratik usahanya masih kurang dari aspek bisnis sesungguhnya. Oleh karena itu, dengan adanya program ini, diharapkan dapat meningkatkan kinerja bisnis dari café ini.

Dalam setiap bisnis, pasti ada permasalahan yang dihadapi. Keunggulan kompetitif merupakan suatu tujuan yang ingin dicapai para pelaku usaha dalam menjalankan usahanya. Tetapi dalam perjalanannya memang tidak mudah, yaitu dapat dimulai dari menyelesaikan berbagai masalah standar yang terjadi di bisnis rumahan. Masalah yang dihadapi oleh Symphony Coffee ialah kurang profesionalnya dalam melakukan pencatatan keuangan dan kurangnya perencanaan pemasaran strategis yang dilakukan. Hal tersebut ditandai dengan tidak adanya buku catatan keuangan yang mencatat setiap transaksi yang dilakukan. Jadi degan tidak adanya pencatatan, maka tidak terlihat omzet dan pendapatan bersih berapa yang dihasilkan tiap bulan. 
Masalah pertama ialah tidak tercipta sistematika dalam melakukan pencatatan keuangan sehingga sulit dilihat mana yang menjadi biaya operasional tetap yang harus dikeluarkan dan juga mana yang menjadi biaya untuk membeli bahan baku kedepannya. Dari masalah ini juga muncul bahwa tidak adanya pemisahan antara dana pribadi sang pemilik dengan profit yang ada di bisnis tersebut. Permasalahan kedua ialah belum adanya perencanaan pemasaran strategis. Karena memang belum ada dokumen sebagai acuan dalam melakukan pemasaran strategis. Pemasaran dapat dikatakan sebagai ujung tombak untuk melakukan eksekusi yang berimbas pada meningkatnya total penjualan. Hal tersebut berujung pada hal positif yaitu adanya peningkatan profit.

Manajemen keuangan adalah suatu proses dalam pengaturan aktivitas atau kegiatan keuangan dalam suatu organisasi dimana didalamnya termasuk kegiatan perencanaan, analisis dan pengendalian terhadap kegiatan keuangan (Brigham dan Houston, 2012). Laporan keuangan dapat diartikan sebagai hasil akhir dari proses akuntansi. Laporan keuangan merupakan alat yang digunakan untuk mengkomunikasikan informasi keuangan dari suatu perusahaan kepada pihak-pihak yang berkepentingan dengan eksistensi suatu perusahaan (Brigham dan Houston, 2012). Tujuan laporan keuangan adalah penyajian informasi mengenai posisi keuangan (financial position), kinerja keuangan (financial performance) dan arus kas (cash flow) dari entitas yang sangat berguna untuk mebuat keputusan ekonomis dari para penggunanya (IAI, 2012:5). Selain mengenai laporan keuangan, hal penting lainnya ialah aktivitas pemasaran. Melakukan sebuah aktivitas pemasaran disini ialah pentingnya perencanaan yang dilakukan oleh suatu usaha. Dimana tujuan akhirnya ialah agar meningkatkan penjualan.

Dalam perspektif keilmuan, marketing merupakan ilmu pengetahuan bersifat objektif yang diperoleh dengan penggunaan beberapa instrumen untuk mengukur kinerja aktivitas bisnis (Hasan, 2018). Pemasaran merupakan proses create, communicate, dan deliver nilai-nilai yang ada dalam suatu produk untuk memenuhi kebutuhan pasar (American Marketing Association dalam Kotler dan Keller, 2016). Marketing diartikan sebagai sebuah disiplin ilmu pengetahuan yang meletakkan asumsi-asumsi dasar yang dapat digunakandalam menciptakan nilai secara optimal (Hasan, 2018). Dalam kajian pemasaran, kegiatan promosi yang efektif dan efisien dapat dimasukkan sebagai bagian dari konsep bauran komunikasi pemasaran. komunikasi pemasaran adalah penggabungan semua unsur dalam bauran pemasaran merek yang memfasilitasi terjadinya pertukaran dengan menciptakan suatu arti yang disebarluaskan kepada pelanggan atau kliennya (Shimp, 2014).

\section{METODOLOGI PELAKSANAAN}

Metode pelaksanaan dalam program pengabdian ini dibagi menjadi tiga tahapan;

1. Tahap pertama yaitu; Pendekatan Masalah. Metode ini bertujuan untuk menyelesaikan persoalan mitra yaitu dengan melakukan diskusi awal antara tim STIE Ekuitas dengan dengan pelaku usaha untuk lebih mendalami apa yang menjadi kendala dan hambatan para pelaku usaha menjalankan usahanya.

2. Prosedur Kerja. Metode ini membahas bagaimana prosedur tersebut dapat dilakukan. Maksudnya ialah prosedur dalam menjalankan program.

3. Kegiatan Pelaksanaan.

Pelaksanaannya antara lain ialah pelatihan manajemen keuangan dan perencanaan pemasaran strategis yang menggunakan modul dan juga terjun implementai langsung di lapangan.

Pelaksanaan pelatihan dalam program ini dapat dibagi menjadi dua bagian. 
Pertama, Pelatihan dan Manual book atau modul aplikasi sistem pencatatan keuangan sederhana untuk memudahkan para pelaku usaha melakukan sistem pencatatan baik pencatatan modal kerja maupun pencatatan manajemen persediaan. Modul tersebut disusun dengan berdasarkan permasalahan dan juga permintaan dari mitra untuk mengembangkan usahanya.

Kedua, pelatihan perencanaan pemasaran strategis untuk meningkatkan brand awareness. Pelatihan ini bertujuan untuk mengembangkan strategi pemasaran secara keseluruhan. Pelatihan ini dibagi menjadi beberapa bagian, antara lain; Business review, Kajian tentang product development yang berujung pada strategi pengembangan produk yang digunakan sebagai dasar melakukan inovasi, Analisis harga demi keselarasan antara harga dengan segmen dan target usaha, Penguatan strategi promosi.

\section{HASIL DAN LUARAN}

Pelatihan pencatatan keuangan dan perencanaan pemasaran strategis dimulai dari pengenalan konsep dasar dan tujuan dari kegiatan ini. Setelah dapat mengidentifikasi masalah, maka selanjutnya dirumuskan materi untuk menjadi solusi dari permasalahan tersebut. Solusi yanv ditawarkan ialah melakukan pengenalan tentnag pencatatan keuangan sederhana dan perencanaan pemasaran strategis demi pengembangan bisnis.

Diawal materi dari modul yang diberikan ialah menjelaskan pengenalan konsep dasar pencatatan keuangan yang membahas tentang mekanisme pembuatan pencatatan keuangan sederhana. Tujuannya ialah untuk memonitoring cash-flow yang ada dan dapat dijadikan dasar pengambilan keputusan strategis kedepannya.

Materi selanjutnya ialah penyusunan perencanaan pemasaran strategis. Dimulai dari business landscape review dari objek usaha kegiatan pengabdian ini. Selanjutnya ialah melakukan screening dari konsep STP (Segmenting, Targeting, dan Positioning).
Dari dua modul ini bertujuan untuk terjadi peningkatkan pengetahuan tentang bisnis yang dijalankan dan sudah mengetahui bagaimana pengembangannya. Hal tersebut dengan cara mengetahui karakter bisnis dari dalam. Selain itu para peserta juga diharapkan dapat memahami bisnis yang sedang dijalankan dan juga memiliki perencanaan kedepannya.

Karena dari materi perencanaan pemasaran strategis ini juga diyakini dapat membentuk bisnis yang berkelanjutan. Karena modul berikutnya ialah pengembangan brand-service-process, yang bertujuan untuk memaksimalkan kekuatan dari dalam dan pelayanan kepada konsumen.

Faktor penghambat yang terjadi dalam pelatihan yang dilaksanakan adalah tidak tersedianya sarana dan prasarana fasilitas pendukung untuk menjalankan pelatihan di ruangan, akan tetapi hal tersebut tidak mengurangi semangat tim untuk memberikan materi. Selanjutnya ialah masalah ketersediaan waktu dari pelaku usaha itu sendiri. Peserta pelatihan tidak dapat meninggalkan pekerjaannya dikarenakan pelatihan diadakan saat jam kerja dan peserta pelatihan sedang mengerjakan pesanan yang cukup banyak. Faktor pendukung yang terjadi dalam pelatihan yang dilaksanakan adalah dimana peserta terlihat semangatnya dalam menjalankan pelatihan yang berakibat banyak terjadi proses diskusi. Pelatihan dan diskusi dilakukan di lapangan secara langsung agar dapat memberikan contoh secara nyata kepada peserta pelatihan.

\section{KESIMPULAN DAN SARAN}

Dalam melakukan suatu usaha haruslah disiplin dalam melakukan pencatatan keuangan dan tidak lupa dengan rencana pemasaran yang akan dilakukan.

Peserta program ini sangat terbantu dengan pelaksanaan program ini, karena memang menyentuh dari permasalahan mereka selama ini. Hal ini bermanfaat bagi peningkatan profit usaha dan 
keberlangsungan bisnis kopi agar dapat berdaya saing tinggi dan para UMKM dengan diadakannya pelatihan manajemen keuangan sederhana dan perencanaan pemasaran strategis ini dapat lebih termotivasi untuk menjadi entrepreneur sejati.

Dalam menjalankan bisnis kedepannya, disarakan untuk selalu disiplin dalam melakukan aktifitas pencatatan keuangan serta selalu merencanakan aktifitas pemasaran kedepannya yang dikaitkan dengan tujuan usaha yang berjalan.

\section{DAFTAR PUSTAKA}

Brigham, Eugene F., dan Joel F. Houston, 2012. Dasar-dasar Manajemen Keuangan. Buku 1, Salemba Empat, Jakarta.

Dokumen Badan Pusat Statistik (Kota Bandung), 2017

Ikatan Akuntan Indonesia (IAI). 2012. Standar Akuntansi Keuangan. Jakarta: IAI.

Kotler, P., and Keller, K., L. (2016), Marketing Management, 15th Edition New Jersey: Pearson Pretice Hall, Inc.

Hasan, A. (2018). MARKETING dan Kasus-Kasus Pilihan. Centre for academic publishing service (CAPS), Yogyakarta. Indonesia.

Shimp, T. A. (2014). Integrated Marketing Communication, Advertising and Promotion. South Western. 